Kong. Res. J. 4(1) : 12-13, 2017

Kongunadu Arts and Science College, Coimbatore.

\title{
A STUDY OF RUSKIN BOND'S “TENACITY OF MOUNTAIN WATER”
}

\author{
Jayasree. A. ${ }^{1}$ and Shobha Ramaswamy ${ }^{2}$ \\ ${ }^{1}$ Dept. of English, Avinashilingam University for Women, Coimbatore. \\ ${ }^{2}$ Dept. of English, Kongunadu Arts and Science College, Coimbatore. \\ E.mail: aj_anand06@yahoo.co.in; ramaswamy.shobha@gmail.com
}

\section{ABSTRACT}

"I am not a religious person but if I were to say I have a religion then I would say I am a nature worshipper."

\section{Ruskin Bond}

Ruskin Bond, a prolific writer, is known for his short stories, novellas and poems and is widely popular especially in Children's Literature Circles. His stories can be likened to an ecological narrative designed to spread awareness about the bitter consequences of human actions that damage the planet's basic life support system. He has received the Sahitya Akademi Award for English writing in India for 'Our Trees Still grow in Dehra' in 1992. He was awarded the Padma Shri in 1999 and Padma Bhushan in 2014. Ruskin Bond's stories breathe his great love and sincere concern for nature which is all encompassing and all pervasive.The prismatic portrayal of nature in Bond's stories enraptures the soul. He draws our sense towards the natural brilliance manifest all around us by presenting a painstakingly drawn out record of the the natural life around him. The amazingly captured landscapes with its myriad forms of life inked by Bond's imagination and his inimitable style come with a strong lesson on the need to protect and preserve nature.

My paper proposes to study Bond's short story entitled "Tenacity of Mountain Water" that explores the interlinked web of life through a simple narrative. Weaving the threads of eco consciousness through the narrative, he marvels at how a tiny rivulet of water becomes a beautiful roaring cascade nourishing and beautifying the entire landscape. The story offers the informed reader a chance to investigate the underlying ecological values and also revisit the human perception of natural resources.

Keywords: Ecocriticism, Ruskin Bond, Nature, Water.

Greg Gerrard in his book Ecocriticism states that Wilderness has a sacramental value. He adds that "The idea of wilderness, signifying nature in a state uncontaminated by civilisation, is the most potent construction of nature available to New World environmentalism. It is a construction mobilised to protect particular habitats and species and is seen as a place for the reinvigoration of those tired of the moral and material pollution of the city"(59). Ecocriticism strives to promote an authentic voice, a viable narrative with nature for its own sake as the touchstone. As ecocritics embark on a path to deliver a new set of eyes to look at the world around us, they lead us into a labyrinth of interactions and negotiations between nature, man and culture. The large scale awareness and emphasis on resolving environmental problems has resulted in placing this mode of criticism in the spotlight.

Literature cannot be an isolated narrative. It brings together the elemental and abstract facets of life assisting reflection, introspection and evolution of the human consciousness. Cheryll
Glotfelty in her 'Literary Critics and the Environmental Crisis' published in Ecoaesthetic and Ecocritical Probings, observes that theorists have identified two basic patterns to perceive literature namely literature as mirror and literature as model (68). In the mirror approach, art imitates life and in the model approach life imitates art. Ecocritics choose literature as a model approach looking for solutions that can help in sustenance of nature and sustained development of life and habitat.

Ruskin Bond, a prolific writer, is known for his short stories, novellas and poems and is widely popular especially in Children's Literature Circles. His stories can be likened to an ecological narrative designed to spread awareness about the bitter consequences of human actions that damage the planet's basic life support system. He has received the Sahitya Akademi Award for English writing in India for 'Our Trees Still grow in Dehra' in 1992. He was awarded the Padma Shri in 1999 and Padma Bhushan in 2014. 
Ruskin Bond's stories breathe his great love and sincere concern for nature which is all encompassing and all pervasive. The prismatic portrayal of nature in Bond's stories enraptures the soul. He draws our attention to the natural brilliance manifest all around us by presenting a painstakingly descriptive record of the the natural life around him. The amazingly captured landscapes with its myriad forms of life inked by Bond's imagination and his inimitable style come with a strong lesson on the need to protect and preserve nature.

Bond, a worshipper of nature explores ecosystems through elaborate descriptions of a variety of plants and animals and scenic elements of nature. His stories gently influence the readers to introspect and reexamine their relationship with nature. Bond strongly believes that the different facets of nature are not only a source of delight but also awaken us spiritually. He explores at length the captivating beauty in every aspect of nature and highlights that every component of nature has its own intrinsic value and role to play in the intricate web of the almighty's design. Bond thus responds to the beauty of a tricking rivulet with the same awe as he would admire the deepest oceans or a patch of beautiful flowers. Bond's short stories are a powerful appeal to sensitise one's approach to nature. Water fascinates Bond and one find's umpteen descriptions and celebrations of water in its myriad forms through the escapades of the narrator who is mostly a child delighting in the presence of a waterfall, a glacier, a hidden lake or rivulet Bond does not believe in a clinical upkeep of nature but revels in the wild mystique and freedom that is the essence of wilderness.

Water is one of the greatest gifts of nature and Bond cannot suppress his excitement at how the tiniest drop of water travels far and wide, through high and low landscapes transforming in size and nature till it reaches the ocean. Water can be likened to survival instinct as it can make its way or rather seep its way through obstacles. In the story 'Tenacity of Mountain Water', the narrator spots a patch of fresh grass and instinctively knows there has to be water underneath. To his delight he discovers a spring of clear sparkling water and exclaims: "I never cease to wonder at the tenacity of water - its ability to make its way through various strata of rock, zigzagging, backtracking, finding space, cunningly discovering faults and fissures in the mountain, and sometimes travelling underground for great distances before emerging into the open. Of course there's no stopping water. For no matter how tiny that little trickle, it has to go somewhere!" (156-157)

The narrator follows the spring and discovers a small ravine wherein the spring had grown in size bubbling with renewed energy. He also briefly sketches the ecosystems formed around the water as it makes way through the rocks into a ravine, trickling through the roof of a cave and cascading off the hill top. Beautiful crimson maidenhair, the narrator's favourite fern, a spotted fork tail, a water spider, a pair of pine martins, patch of primrosesall offer him moments of delight. The spring then becomes a rivulet slowly expanding into a small stream. It then transforms into a waterfall and as a strong river speeds down into the valley. Unable to follow further, the narrator looks over the landscape and sees the distant silver of a meandering river and knew that his river is destined to join it and the combined rivers would become one with the Ganga which in turn fertilising the alluvial plains of northern India would merge into the Bay of Bengal. (158) The narrator further observes: "And the ocean, what is it but another droplet in the universe, in the greater scheme of things.? No greater than the glistening drop of water that helped start it all..."(158).

'Tenacity of Mountain Water' explores the interlinked web of life through a simple narrative. Wilderness allows for redemption, a spiritual sojourn, a mediation with the self and a million possibilities for a new you, a new world.Weaving the threads of eco consciousness through the narrative, the story offers the informed reader a chance to investigate the underlying ecological values and also revisit the human perception of natural resources. The need of the hour is not how man is and how he can be but rather what he can do to make the world a better place. The most important function of literature today is to channelise all energies into awareness of the fact that the human is an integral part of nature. Nature is not for man's disposal and destruction of nature will soon lead to the destruction of man himself.

\section{REFERENCES}

Bond, Ruskin, 2007. Nature Omnibus: A Bond with Nature. New Delhi: Ratna Sagar.

Garrad, Greg, 2004. Ecocriticism. London: Routledge.

Dwivedi Rini and Anu Shukla, 2009. Ecoaesthetic and Ecocritical Probings. New Delhi: Sarup. 